\title{
Correction to: Inhibition of mTORC1 through ATF4-induced REDD1 and Sestrin2 expression by Metformin
}

Se-Kyeong Jang ${ }^{1,2}$, Sung-Eun Hong ${ }^{3}$, Da-Hee Lee ${ }^{1}$, Ji-Young Kim³ ${ }^{3}$ Ji Yea Kim', Sang-Kyu Ye ${ }^{4}$, Jungil Hong ${ }^{2}$, In-Chul Park ${ }^{* *}$ and Hyeon-Ok Jin ${ }^{3^{*}}$

\section{Correction to: BMC Cancer 21, 803 (2021). https://doi.org/10.1186/s12885-021-08346-x}

Following publication of the original article [1], the authors reported that the electrophoretic blots of Figs. 1A, B, 2A, C, E, 3A, C, E, 4A, B, C, D, 5A, B, C, 6B, D, and F were published in their raw format. The edited versions of the complete figures are given below and the original article [1] has been corrected.

* Correspondence: parkic@kirams.re.kr; hyeonok@kirams.re.kr

${ }^{1}$ Division of Fusion Radiology Research, Korea Institute of Radiological \& Medical Sciences, 75 Nowon-ro, Nowon-gu, Seoul 01812, Republic of Korea ${ }^{3}$ KIRAMS Radiation Biobank, Korea Institute of Radiological and Medical Sciences, 75 Nowon-ro, Nowon-gu, Seoul 01812, Republic of Korea

Full list of author information is available at the end of the article

(c) The Author(s). 2021 Open Access This article is licensed under a Creative Commons Attribution 4.0 International License, which permits use, sharing, adaptation, distribution and reproduction in any medium or format, as long as you give appropriate credit to the original author(s) and the source, provide a link to the Creative Commons licence, and indicate if changes were made. The images or other third party material in this article are included in the article's Creative Commons licence, unless indicated otherwise in a credit line to the material. If material is not included in the article's Creative Commons licence and your intended use is not permitted by statutory regulation or exceeds the permitted use, you will need to obtain permission directly from the copyright holder. To view a copy of this licence, visit http://creativecommons.org/licenses/by/4.0/. The Creative Commons Public Domain Dedication waiver (http://creativecommons.org/publicdomain/zero/1.0/) applies to the data made available in this article, unless otherwise stated in a credit line to the data. 


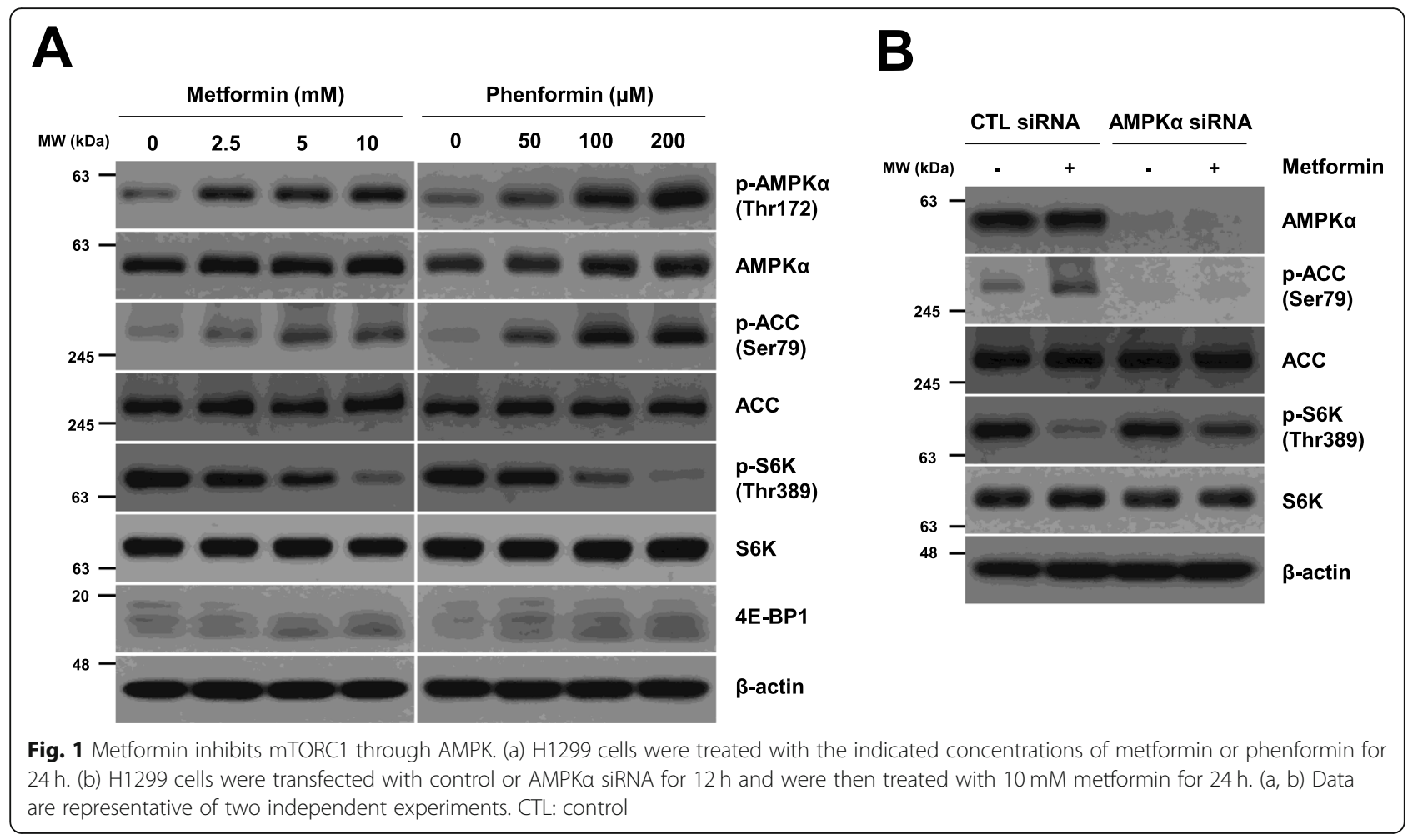




\section{A}
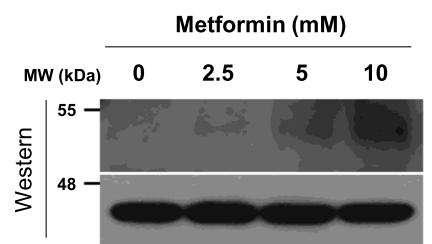

ATF4

$\beta$-actin

C
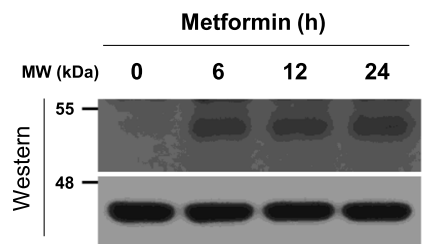

ATF4

$\beta$-actin

E

CTL SIRNA ATF4 SiRNA

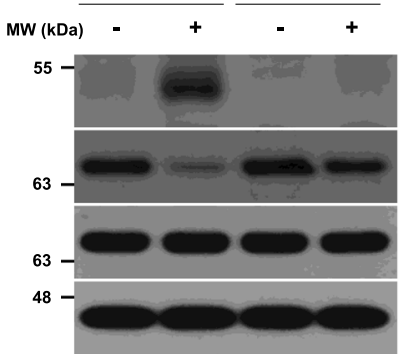

B

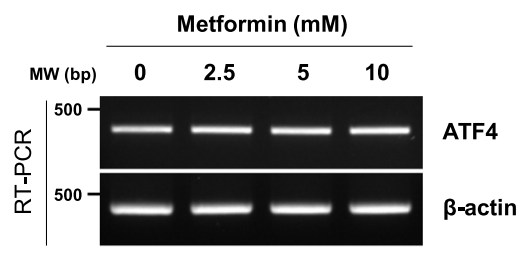

D

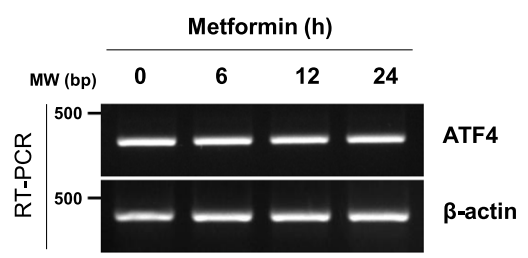

F

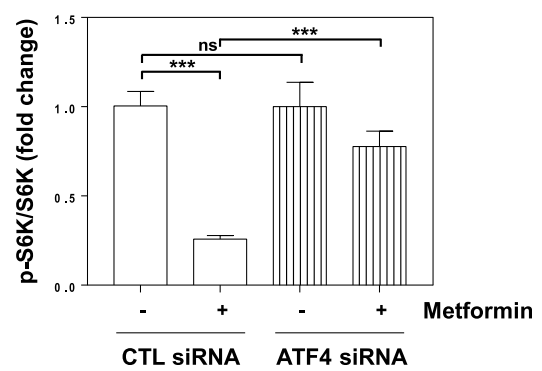

Fig. 2 Metformin inhibits mTORC1 through ATF4. (a, b) H1299 cells were treated with the indicated concentrations of metformin for $24 \mathrm{~h}$. (c, d) H1299 cells were treated with $10 \mathrm{mM}$ metformin for the indicated time. The protein levels $(\mathrm{a}, \mathrm{c})$ and mRNA levels (b, d) were estimated by western blot and RT- PCR analysis, respectively. (a-d) Data are representative of two independent experiments. (e, f) H1299 cells were transfected with control or ATF4 siRNA for $12 \mathrm{~h}$ and were then treated with $10 \mathrm{mM}$ metformin for $24 \mathrm{~h}$. (e) Data are representative of three independent experiments. ( $f$ ) The p-S6K expression was quantified using ImageJ software and fold change with respect to control after normalization to respective S6K bands was plotted as histogram. $(n=3$; ***P $<0.001$; NS, not significant). CTL: control 
A

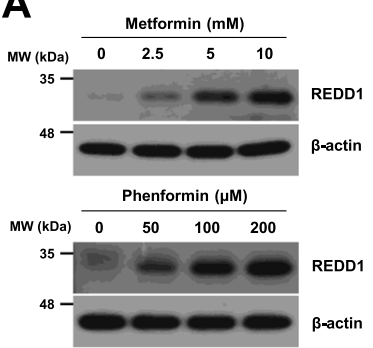

C

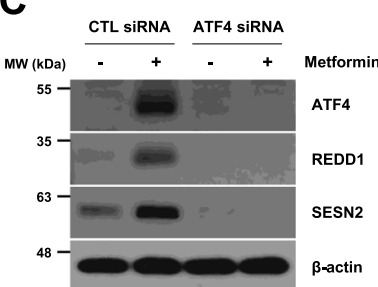

$\mathbf{E}$

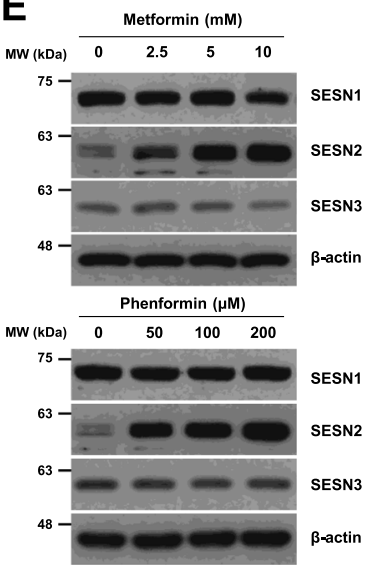

B

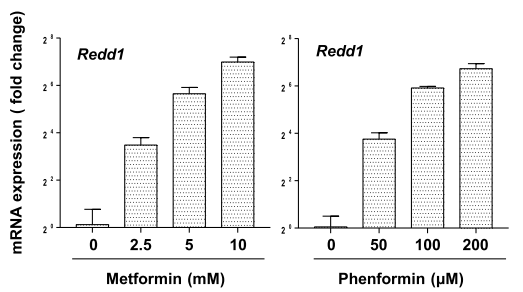

D

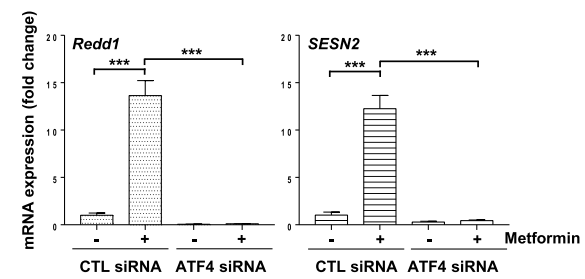

$\mathbf{F}$
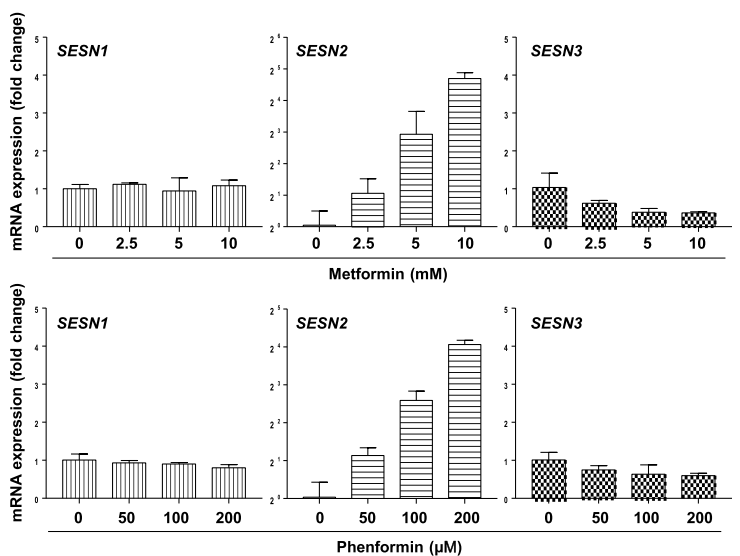

Fig. 3 Metformin induces the expression of REDD1 and Sestrin2 in an ATF4-dependent manner. (a, b, e, f) H1299 cells were treated with the indicated concentrations of metformin or phenformin for $24 \mathrm{~h}$. (c, d) H1299 cells were transfected with control or ATF 4 siRNA for $12 \mathrm{~h}$ and were then treated with $10 \mathrm{mM}$ metformin for $24 \mathrm{~h}$. The protein levels $(a, c, e)$ and mRNA levels $(b, d, f)$ were estimated by western blot and real-time PCR analysis, respectively. $(a, c, e)$ The western blot is representative of two independent experiments. $(b, d, f)$ The real-time PCR results for each sample were analysed according to the $2^{-\Delta \Delta C t}$ method using $\beta$-actin as the internal control. Gene transcription is presented as the fold change relative to the control sample $\left(n=3 ;{ }^{* * *} P<0.001\right)$. CTL: control, SESN1: Sestrin1, SESN2: Sestrin2, SESN3: Sestrin3 
A

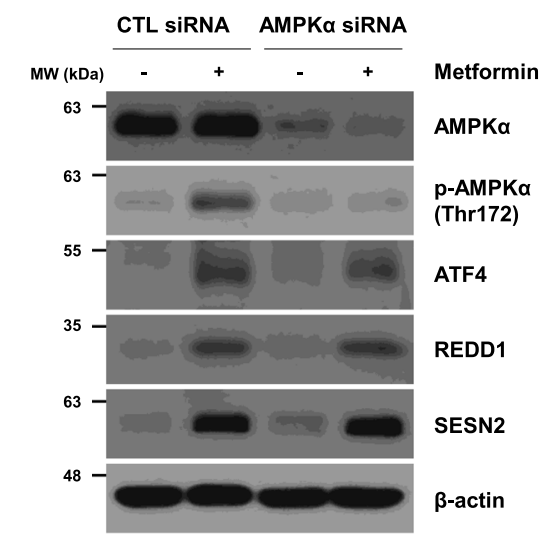

C

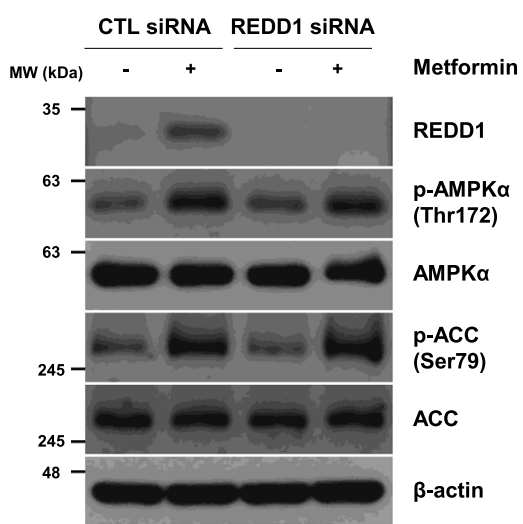

B

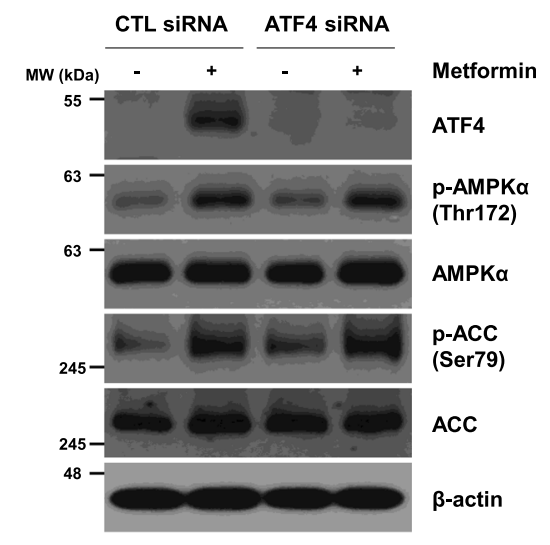

D

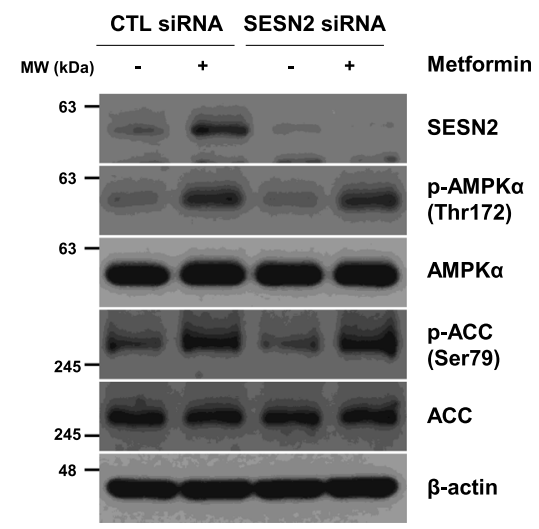

Fig. 4 AMPK and ATF4 do not affect each other's expression under metformin treatment. (a-d) H1299 cells were transfected with control, AMPKa, ATF4, REDD1, or Sestrin2 siRNA for $12 \mathrm{~h}$ and then treated with $10 \mathrm{mM}$ metformin for $24 \mathrm{~h}$. The indicated protein levels were estimated by western blot analysis. The blot is representative of two independent experiments. CTL: control, SESN2: Sestrin2 


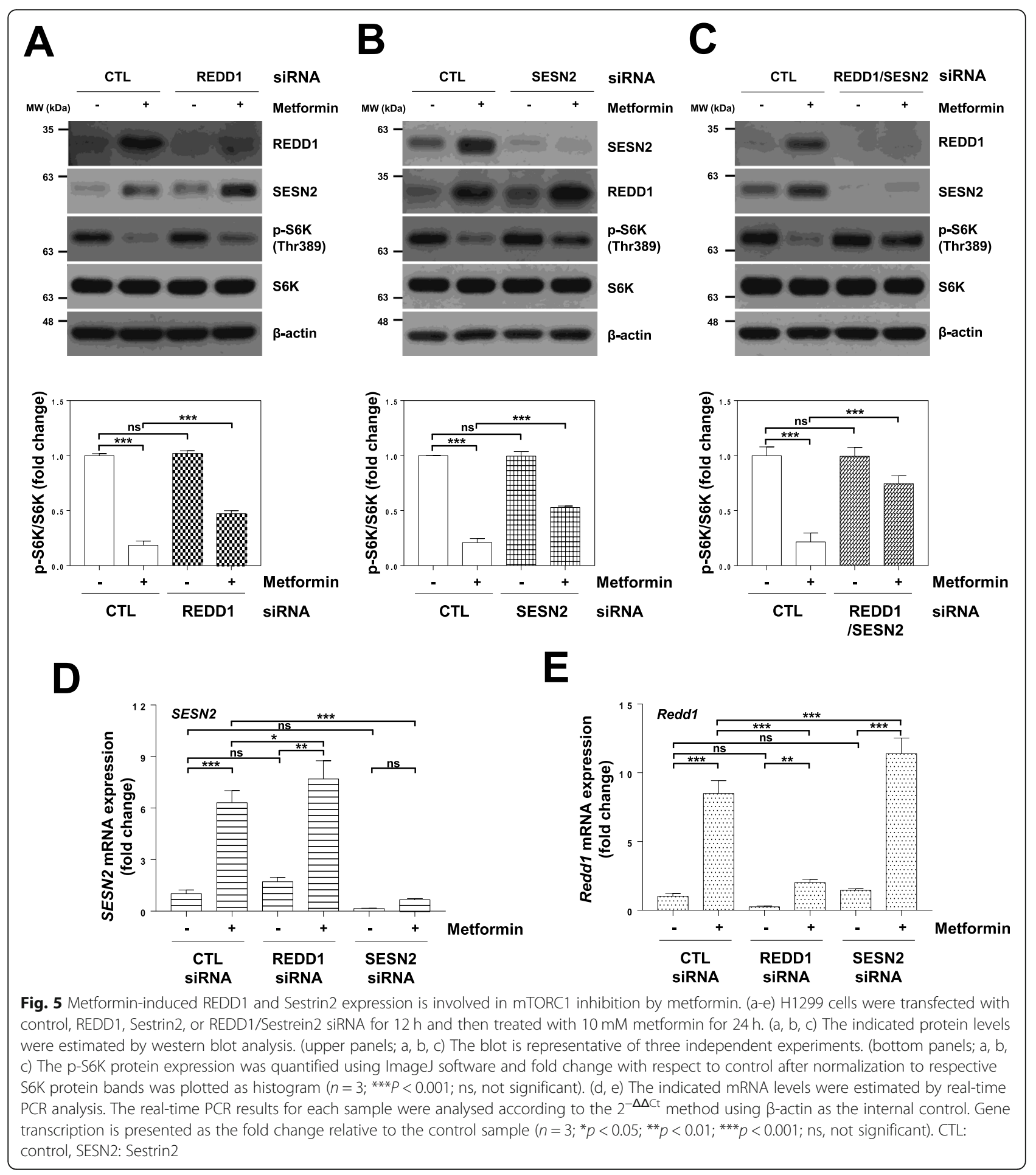




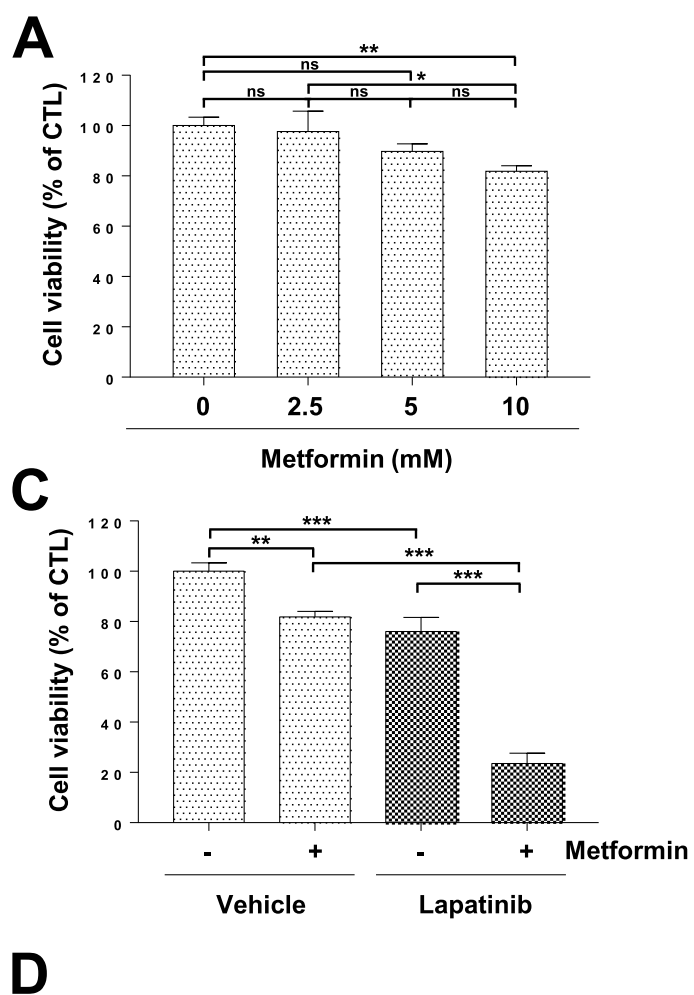

\section{B}
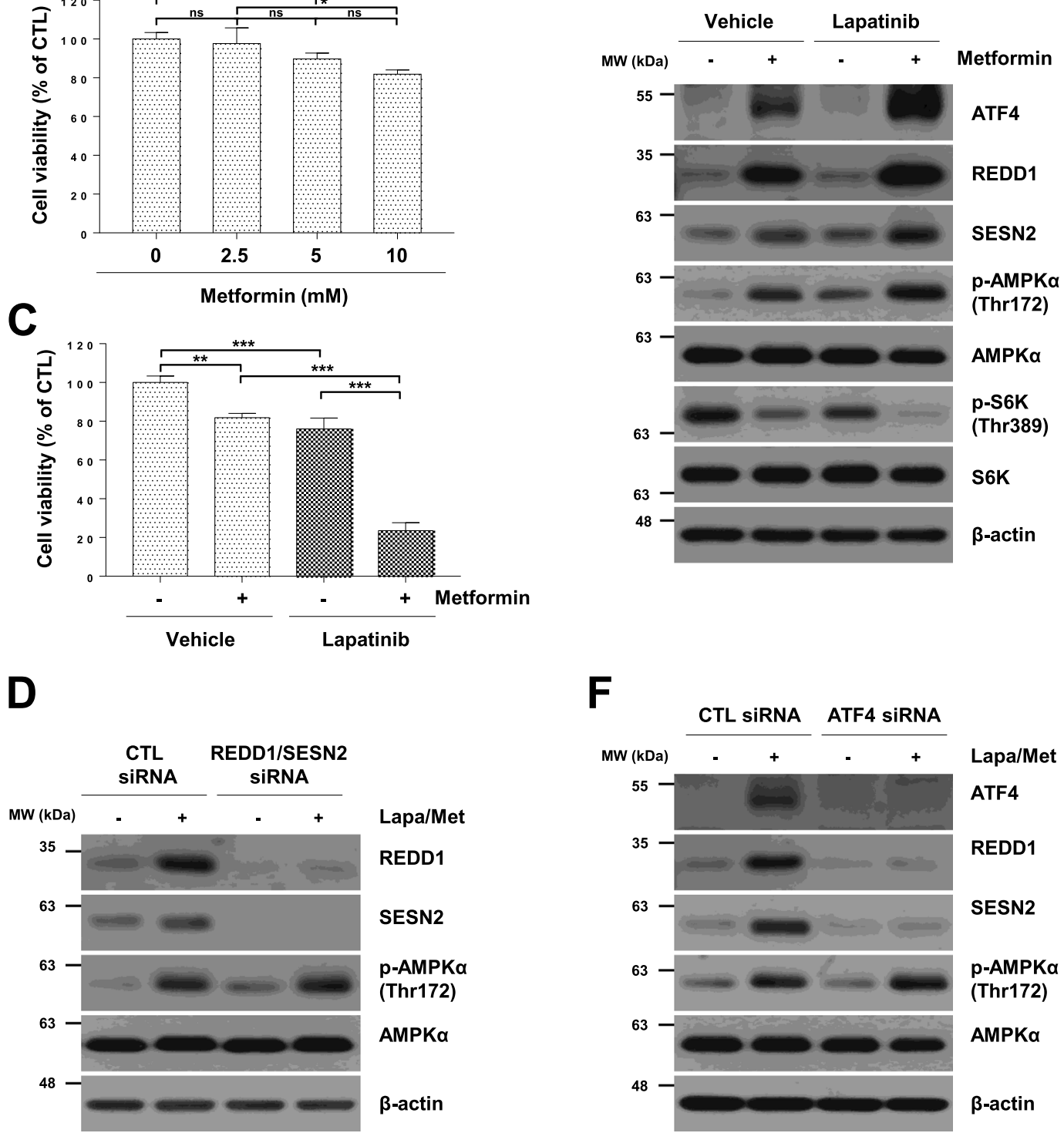

F

E

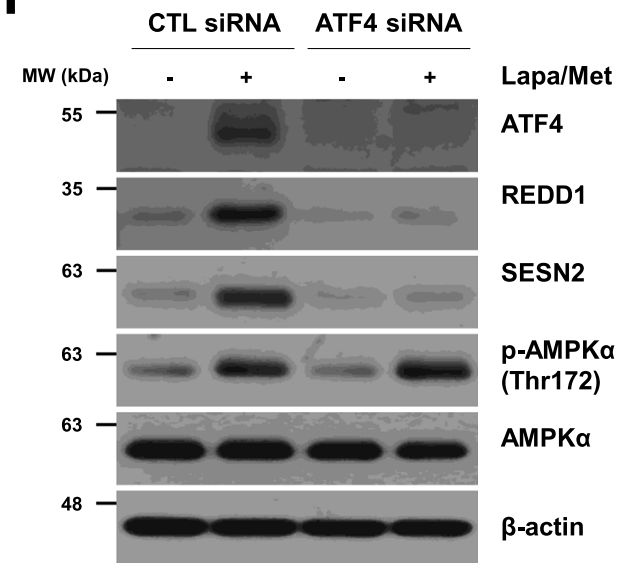

G
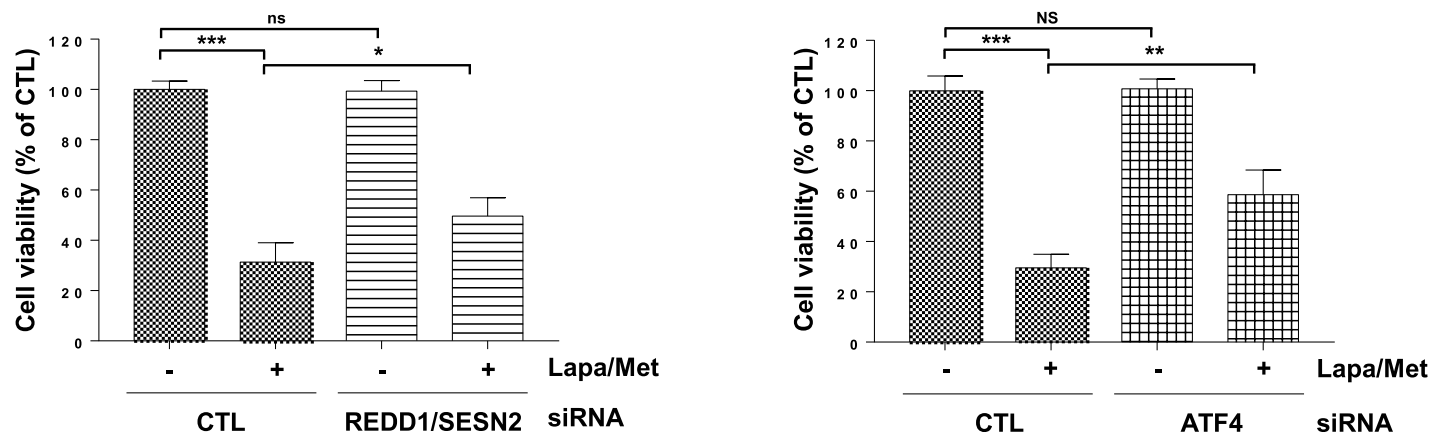

Fig. 6 (See legend on next page.) 
(See figure on previous page.)

Fig. 6 Lapatinib enhances cell sensitivity to metformin, and knockdown of REDD1 and Sestrin2 decreases cell sensitivity to metformin and lapatinib. (a) H1299 cells were treated with the indicated concentrations of metformin for $24 \mathrm{~h}$. (b) H1299 cells were treated with $10 \mathrm{mM}$ metformin and/or $10 \mu \mathrm{M}$ lapatinib for $12 \mathrm{~h}$. (c) H1299 cells were treated with $10 \mathrm{mM}$ metformin and/or $10 \mu \mathrm{M}$ lapatinib for $24 \mathrm{~h}$. (d, f) H1299 cells were transfected with control, ATF4 or REDD1/Sestrin2 siRNA for $12 \mathrm{~h}$ followed by treatment with $10 \mathrm{mM}$ metformin and $10 \mu \mathrm{M}$ lapatinib for $12 \mathrm{~h}$. $(\mathrm{e}, \mathrm{g}) \mathrm{H} 1299$ cells were transfected with control, ATF4, or REDD1/Sestrin2 siRNA for $12 \mathrm{~h}$ followed by treatment with $10 \mathrm{mM}$ metformin and $10 \mu \mathrm{M}$ lapatinib for $24 \mathrm{~h}$. (a. c, e, g) Cell viability was measured by MTT assay. The data are presented as the mean percentage of control \pm SD relative to the control $\left(n=3 ;{ }^{*} p<0.05 ;{ }^{* *} p<0.01 ;{ }^{* * *} p<0.001\right.$; ns, not significantly different). (b, d, f) The indicated protein levels were estimated by western blot analysis. Data are representative of three independent experiments. CTL: control, Lapa: Lapatinib, Met: metformin, SESN2: Sestrin2

\section{Author details}

${ }^{1}$ Division of Fusion Radiology Research, Korea Institute of Radiological \& Medical Sciences, 75 Nowon-ro, Nowon-gu, Seoul 01812, Republic of Korea. ${ }^{2}$ Department of Food and Microbial Technology, Seoul Women's University, 621 Hwarangro, Nowon-gu, Seoul 01797, Republic of Korea. ${ }^{3}$ KIRAMS Radiation Biobank, Korea Institute of Radiological and Medical Sciences, 75 Nowon-ro, Nowon-gu, Seoul 01812, Republic of Korea. ${ }^{4}$ Department of Pharmacology, Seoul National University College of Medicine, 103 Daehak-ro, Jongno-gu, Seoul 03080, Republic of Korea.

\section{Published online: 02 August 2021}

\section{Reference}

1. Jang SK, Hong SE, Lee DH, Kim JY, Kim JY, Ye SK, et al. Inhibition of mTORC1 through ATF4-induced REDD1 and Sestrin2 expression by metformin. BMC Cancer. 2021;21(1):803. https://doi.org/10.1186/s12885-02108346-x. 